\title{
Large oral focal mucinosis: a case report
}

\author{
Mucinose oral focal: descrição de um caso clínico
}

Karla Rovaris da Silva'; Bárbara Vanessa de Brito Monteiro²; Thayse Silva Aragão Norões3;

Gustavo Pina Godoy ${ }^{4} ;$ Márcia Cristina da Costa Miguel ${ }^{5}$

\begin{abstract}
The aim of this article is to report the case of a 23-year-old female patient that sought dental service for examination of an asymptomatic slow-growing large lump in the mandibular gingiva causing displacement of the right first molar. Excisional biopsy, histopathological analysis, Alcian blue/periodic acid-Schiff (PAS) staining and immunohistochemistry analysis for S-100 were performed. The diagnosis established was oral focal mucinosis. After three years, the patient is still under follow-up, without any recurrences. Although cases of oral focal mucinosis of this particular size are rare, this entity should be considered in the differential diagnosis of oral lesions located in the gingiva.
\end{abstract}

Key words: connective tissue diseases; connective tissue; Alcian blue.

\section{INTRODUCTION}

Oral focal mucinosis (OFM) is an asymptomatic, rarely reported, benign lesion of the oral cavity whose etiology is uncertain $^{(7)}$. Tomich ${ }^{(9)}$ first described OFM as the oral counterpart of cutaneous focal mucinosis. It has been suggested that its pathogenesis involves fibroblasts over producing hyaluronic acid at the expense of connective tissue elements ${ }^{(2,9)}$.

OFM commonly occurs during the fourth to fifth decade of life, and females are more frequently affected than males, with a ratio of almost $2: 1^{(5)}$. This lesion appears as an asymptomatic elevated swelling, with the same color of the surrounding normal mucosa, and the mucosa directly overlying bone appears to be the particularly vulnerable ${ }^{(6)}$. OFM is $1 \mathrm{~cm}$ or less in diameter ${ }^{(3-5)}$. Rarely, the lesion may become secondarily ulcerated ${ }^{(8)}$. In this article, we report the case of an uncommonly large oral focal mucinosis in a female.

\section{CASE REPORT}

A 23-year-old female patient sought dental service for examination of an asymptomatic slow-growing lump in the mandibular gingiva causing displacement of the right first molar. The lesion was sessile, firm, and the overlying mucosa was non-ulcerated and presented no colour alterations (Figure A). The diagnostic hypotheses were peripheral giant cell lesion, peripheral ossifying fibroma and traumatic fibroma. Excisional biopsy and histopathological analysis were performed. In the subepithelial area, circumscribed masses of loose myxomatous tissue were observed, surrounded by dense fibrous connective tissue separating them from the epithelial lining (Figure B). Within the myxomatosis area, an evident proliferation of ovoid, stellate and spindle cells was observed. Alcian blue/periodic acid-Schiff (PAS) staining was performed and revealed a strong and diffuse positivity, which confirmed the abundant mucinous material

First submission on 05/08/13; last submission on 09/10/13; accepted for publication on 10/10/13; published on 20/02/14

1. Doctoral student of Oral Radiology at Universidade Estadual de Campinas (Unicamp); Master's degree in Oral Radiology from Unicamp.

2. Doctoral student of Oral Pathology at Universidade Federal do Rio Grande do Norte (UFRN); Master's degree in Oral Pathology from UFRN

3. Dentistry graduate of Universidade Estadual da Paraíba (UEPB).

4. Doctorate in Oral Pathology from UFRN; professor of the Post-Graduate Program in Dentistry at UEPB.

5. Doctorate in Oral Pathology from UFRN; professor of the Post-Graduate Program in Oral Pathology at UFRN. 
dispersed throughout the connective tissue compatible with hyaluronic acid (Figure C). Immunohistochemistry analysis for S-100 protein showed that the lesion was negative for this marker in the mucinous area (Figure D). The established diagnosis was oral focal mucinosis. After three years, the patient is still under follow-up, without any recurrences.
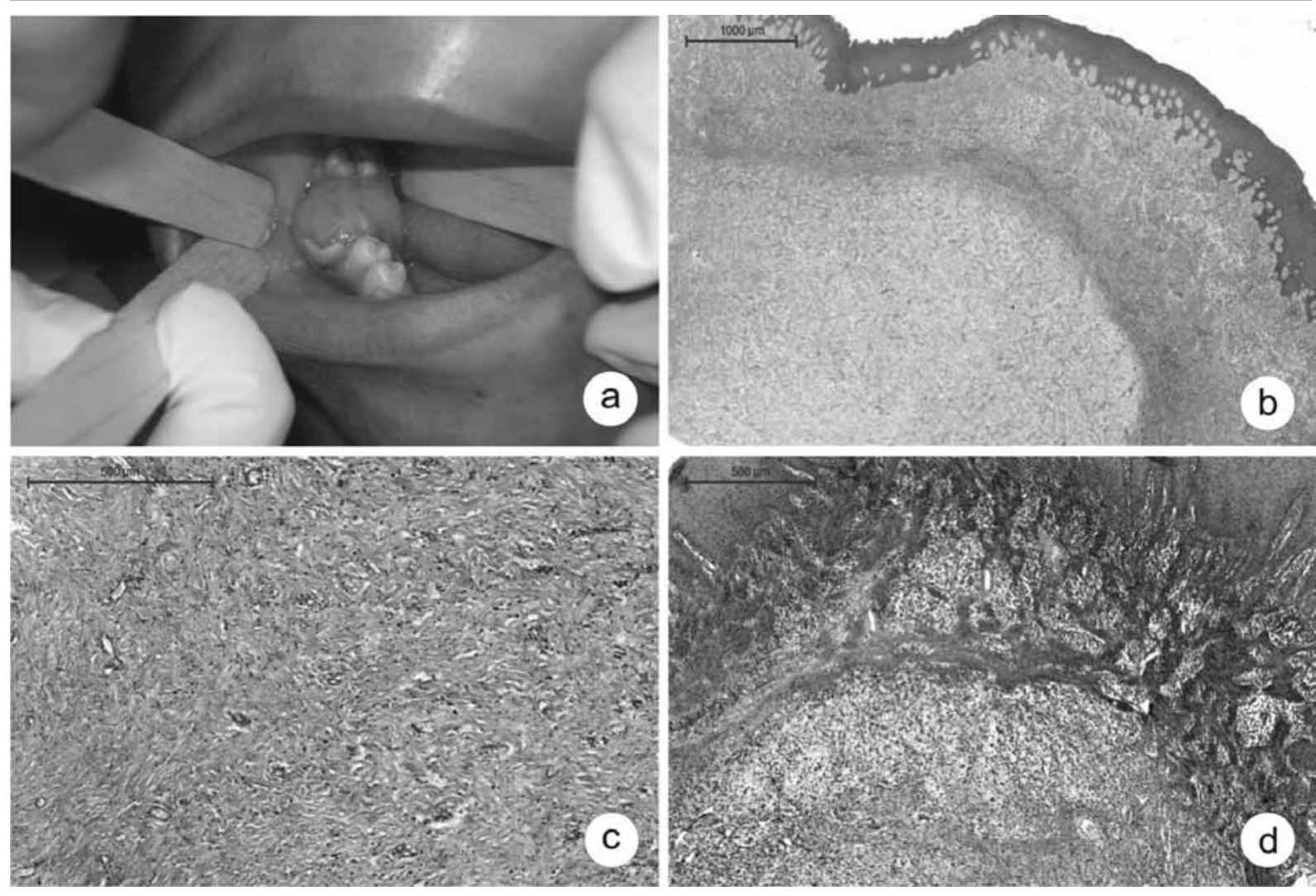

FIGURE - A) Clinical aspect of the lesion causing tooth displacement; B) circumscribed mucinosis area covered with stratified squamous epithelium; $C$ ) alcian blue positivity in mucinosis area; D) immunobistochemistry for $\$ 100$ showing negativity in the myxoid area and positivity in Langerbans cells

\section{DISCUSSION}

According to Narayana and Casey ${ }^{(7)}$, OFM is routinely misdiagnosed. Histopathological diagnosis becomes important because it is difficult to diagnose this lesion clinically, as there are no clinical distinctive features ${ }^{(6)}$. OFM can manifest as pyogenic granuloma, peripheral giant cell granuloma, or peripheral ossifying fibroma ${ }^{(7)}$. In this case, the lesion was particularly large and caused displacement of the first right molar, what made an accurate clinical diagnosis impossible.

The histological findings of OFM described in the literature are: a well-circumscribed area of myxoid tissue surrounded by fibrotic tissue. The myxomatosis/mucinosis area is a loose connective tissue composed by an accumulation of hyaluronic acid and collagen fibrils that are widely separated and interspersed with stellate-shaped fibroblasts, with or without inflammation, and covered with stratified squamous epithelium $^{(1,2,5,7)}$. All the histological features were observed in the present case.

OFM specimens are Alcian blue-positive, showing strong and diffuse positivity, which confirms the abundant mucin dispersed throughout the connective tissue ${ }^{(2,8)}$. As the differential diagnosis also includes myxoid neural lesions, $\mathrm{S} 100$ staining is important in establishing the diagnosis, with cases of OFM being negative ${ }^{(1)}$. In our case, negativity for $\mathrm{S} 100$ was observed in the mucinous area, what reinforced the diagnosis of OFM.

Similar to this reported case, a case series ${ }^{(7)}$ described female predilection, and the majority of lesions were located on the mandibular gingiva. In all reported cases, the histologic features, combined with negative immunohistochemical S-100-protein expression, fulfill the diagnostic criteria.

Surgical excision is the recommended treatment for OFM, and recurrences are unusual ${ }^{(7)}$. The present patient shows no recurrence 
three years after the surgical excision. This case is particularly interesting because the lesion was atypical in appearance and size. Furthermore, a tooth displacement was clinically observable.
Although cases of oral focal mucinosis of this size are rare, this entity should be considered in the differential diagnosis of soft tissue lesions in the oral cavity, especially when located in the gingiva.

\section{RESUMO}

O objetivo deste artigo é relatar o caso de uma paciente de 23 anos de idade que procurou o serviço odontológico para exame de um grande nódulo de crescimento lento, assintomático, na gengiva mandibular, o que causou deslocamento do primeiro molar direito. Foram realizadas biópsia excisional, análise bistopatológica, coloração Alcian blue/periodic acid-Schiff (PAS) e análise imuno-histoquímica para S-100. O diagnóstico de mucinose oral focal foi estabelecido. A paciente ainda está sob acompanhamento, sem recorrência, após três anos. Embora os casos de mucinose oral focal com esse tamanho sejam raros, esta entidade deve ser considerada no diagnóstico diferencial das lesões orais localizadas em gengiva.

Unitermos: doenças do tecido conjuntivo, tecido conjuntivo, azul alciano.

\section{REFERENCES}

1. ALDRED, M. J. et al. Oral focal mucinosis: report of 15 cases and review of the literature. Pathology, v. 35, n. 5, p. 393-6, 2003.

2. GABAY, E.; AKRISH, S.; MACHTEI, E. E.; Oral focal mucinosis associated with cervical external root resorption: a case report. Oral Surg Oral Med Oral Pathol Oral Radiol Endod, v. 110, n. 4, p. e75-8, 2010.

3. IEZZI, G. et al. Oral focal mucinosis of the gingiva: case report. $J$ Periodontol, v. 72, n. 8, p. 1100-2, 2001.

4. LEE, J. G. et al. Oral focal mucinosis in an adolescent: a case report. Aust Dent J, v. 57, n. 1, p. 90-2, 2012.
5. LIMA, A. A. S. et al. Oral focal mucinosis. Quintessence Int, v. 99, n. 7, p. 611-5, 2008.

6. MADHUSUDHAN, A. S. et al. Oral focal mucinosis: report of two cases. Rev Odonto Cienc, v. 25, n. 3, p. 310-3, 2010.

7. NARAYANA, N. CASEY, J. Oral focal mucinosis: review of the literature and seven additional cases. Gen Dent, v. 57, n. 2, p. e11-3, 2009.

8. TALACKO, A. A. et al. Oral focal mucinosis: report of two cases with ulceration. Pathology, v. 36, n. 6, p. 582-3, 2004.

9. TOMICH, C. E. Oral focal mucinosis. A clinicopathologic and histochemical study of eight cases. Oral Surg Oral Med Oral Pathol, v. 38 , n. 5, p.714-24, 1974.

\section{MAILING ADDRESS}

